\title{
Krzysztof Kułak
}

Uniwersytet Marii Curie-Skłodowskiej w Lublinie krzysztof.kuak@wp.pl

\section{Kwestia niezależności prokuratora w nowej ustawie - Prawo o prokuraturze}

\author{
The Issue of the Prosecutor's Autonomy in the New Act - \\ Law on the Prosecutor's Office
}

\section{STRESZCZENIE}

Artykuł porusza problematykę niezależności prokuratora. Przedstawiono w nim rozwój i sposób kształtowania się niezależności prokuratora w ujęciu historycznym, a następnie dokonano analizy niezależności w ustawie - Prawo o prokuraturze. Głównym elementem opracowania jest uwypuklenie potrzeby rozróżniania kwestii niezależności zewnętrznej prokuratury (jako jednostki organizacyjnej) oraz niezależności wewnętrznej prokuratora (jako stosunku między przełożonym a podwładnym). Jeżeli chodzi o niezależność zewnętrzną, to szczególną uwagę poświęcono kwestii połączenia funkcji Ministra Sprawiedliwości i Prokuratora Generalnego. Autor wyciągnął także wniosek, że w nowej ustawie - Prawo o prokuraturze nie można już mówić o niezależności prokuratora jako o zasadzie ustrojowej. W zakończeniu przeanalizował poglądy na temat potrzeby i celowości kształtowania prokuratury na zasadzie niezależności oraz przedstawił własny pogląd na temat najbardziej optymalnego zbudowania niezależności prokuratora.

Słowa kluczowe: zasada niezależności prokuratora w ujęciu wewnętrznym i zewnętrznym; niezależność prokuratora w ujęciu (rozwoju) historycznym; kwestia łączenia stanowiska Ministra Sprawiedliwości i Prokuratora Generalnego

Od czasu powstania instytucji prokuratury w Polsce była ona ukształtowana na zasadach podporządkowania i zależności ${ }^{1}$. Patrząc na prokuraturę z punktu

${ }^{1}$ Zob. L. Mazowiecka, Prokuratura w Polsce (1918-2014), Warszawa 2015, s. 74-75, 108-111, 122-130; M. Mistygacz, Ustrój prokuratury w Polsce. Tradycja i współczesność, Warszawa 2013, s. 50-55, 199-204; H. Zięba-Załucka, Instytucja prokuratury w Polsce, Warszawa 2003, s. 11-15, 29-30; A. Kiełtyka, R. Skrzypek, A. Gadzała, Ochrona konstytucyjnych praw i wolności człowieka 
widzenia rysu historycznego, z łatwością można zauważyć, że kwestia jej niezależności była zawsze głównym elementem stanowiącym o jej pozycji i sposobie funkcjonowania. Problematyka ta jest tym bardziej istotna w związku z nowo uchwaloną ustawą z dnia 28 stycznia 2016 r. -Prawo o prokuraturze 2.

W systemie prawa polskiego nie ma definicji legalnej pojęcia niezależności. Powszechnie pojmuje się ją jako niepodporządkowanie komuś lub czemuś, rozporządzanie sobą, samodzielność ${ }^{3}$. W tym znaczeniu na niezależność prokuratora można spoglądać pod względem kilku aspektów, a w szczególności z punktu widzenia niezależności ustrojowej i procesowej. W pierwszym przypadku można jeszcze wyróżnić aspekt wewnętrzny niezależności prokuratora (stosunek między przełożonym a podwładnym) i zewnętrzny (tj. zależność prokuratury jako jednostki organizacyjnej od innych organów państwa), a w drugim - swobodę (samodzielność) podejmowania decyzji na etapie prowadzonego postępowania przygotowawczego lub udziału w postępowaniu sądowym. O niezależności wewnętrznej prokuratora świadczy zakres możliwości ingerowania przez prokuratora przełożonego w pracę (samodzielność) prokuratora podległego, natomiast o niezależności zewnętrznej - sposób powiązania (zależności) prokuratury z innymi organami państwa. Niezależność zewnętrzna prokuratury nie musi się przekładać na niezależność wewnętrzną prokuratora i odwrotnie. Są to dwa różne elementy, które mogą być odmiennie uregulowane.

Na status prokuratora można także patrzeć z punktu widzenia elementów, które stanowią o jego pozycji (tzw. niezależność ustrojowa sensu stricto), jak np. zakaz przynależności do partii politycznych i prowadzenia działalności politycznej, immunitet formalny i materialny, ograniczenia prawa przenoszenia prokuratora na inne miejsce służbowe itp.

W uproszczony sposób można powiedzieć, że prokurator samodzielnie (jednoosobowo) wykonuje czynności procesowe, a wyjątkiem jest współpraca z innym prokuratorem albo $\mathrm{w}$ zespole ${ }^{4}$. Na etapie postępowania przygotowawczego nie ma przypadków kolegialnego podejmowania decyzji przez prokuratorów.

i obywatela w działalności prokuratury Rzeczypospolitej Polskiej, [w:] Godność obywatela, urzędu $i$ instytucji. Zmiany prawnoustrojowe prokuratury RP, red. H. Zięba-Załucka, M. Kijowski, Rzeszów 2005, s. 37-42; J. Gurgul, Prokurator w II Rzeczypospolitej - zagadnienia wybrane, „Prokuratura i Prawo" 1999, nr 11-12, s. 8-20.

${ }^{2}$ Ustawa z dnia 28 stycznia 2016 r. - Prawo o prokuraturze (Dz.U., poz. 177), dalej jako: p.o.p. Razem z tą ustawą uchwalono przepisy wprowadzające ustawę - Prawo o prokuraturze (Dz.U., poz. 178), a zgodnie z treścią art. 1 wymieniona ustawa weszła w życie w dniu 4 marca $2016 \mathrm{r}$.

${ }^{3}$ Stownik języka polskiego, red. M. Szymczak, t. 2, Warszawa 1984, s. 373.

${ }^{4}$ Pewnym elementem niesamodzielności w pracy prokuratora jest konieczność uzyskania przez asesora prokuratury aprobaty prokuratora bezpośrednio przełożonego na wydanie decyzji o zawieszeniu postępowania, kończącej postępowanie przygotowawcze, sporządzenie aktu oskarżenia, środków odwoławczych i środków zaskarżenia (art. $173 \S 2$ p.o.p.). Ponadto nowa ustawa - Prawo o prokuraturze wyraźnie przewiduje, że zadania prokuratora mogą być realizowane w ramach zespołów prokuratorów, powoływanych zarządzeniem kierownika nadrzędnej jednostki organizacyjnej prokuratury (art. $56 \S 2$ p.o.p., zob. też art. $63 \S 3$ i 4 p.o.p.). Nie zmienia to jednak modelu jednoosobowego podejmowania przez prokuratora decyzji procesowych. 
Rozwój historyczny prokuratury pokazuje, że nie przetrwała ona nigdy w żadnym ze swoich kształtów ustrojowych zbyt długo, a każdy jej sposób funkcjonowania był ściśle i w głównej mierze związany z kwestią niezależności.

W doktrynie wyróżnia się kilka modeli funkcjonowania prokuratury:

- francuski (klasyczny),

- związany z władzą ustawodawczą (parlamentarny),

- podporządkowany głowie państwa,

- ograniczonej niezawisłości.

Wariant klasyczny polega na hierarchicznym podporządkowaniu prokuratorów Ministrowi Sprawiedliwości, czyli władzy wykonawczej. Występuje on np. we Francji, w Austrii, Belgii, Czechach, Hiszpanii, Holandii, Niemczech, Polsce (do 2010 r.) [...]. W systemie parlamentarnym prokuratura podporządkowana jest parlamentowi wybierającemu Prokuratora Generalnego. System ten występuje m.in. w Rosji, na Słowenii, w Macedonii, na Białorusi, Ukrainie, Węgrzech [...]. Model podporządkowania prokuratury głowie państwa krótko występował w Polsce po zniesieniu Rady Państwa w 1989 r. i powierzeniu Prezydentowi RP prawa do powoływania Prokuratora Generalnego. Istniał do momentu gruntownej nowelizacji ustawy o prokuraturze w $1990 \mathrm{r}$. Występuje on w Belgii, Bułgarii, Grecji, Hiszpanii. Wariant ograniczonej niezawisłości (włoski) istnieje we Włoszech. Na podstawie konstytucji prokuratura korzysta z gwarancji, jakie prawo zapewnia ustrojowi sądów. Prokuratorzy podlegają Wyższej Radzie Magistratury i są przez nią mianowani. Niezawisłość posiadają tylko szefowie poszczególnych prokuratorów oraz prokuratura jako organ państwowy. Prokurator podlega szefowi jednostki prokuratury ${ }^{5}$.

W Polsce w okresie dwudziestolecia międzywojennego prokuratura (wówczas: Urząd Prokuratorski) wchodziła w skład władzy sądowniczej. Ustrój tego organu był regulowany przez rozporządzenie Prezydenta RP z dnia 6 lutego $1928 \mathrm{r}$. - Prawo o ustroju sądów powszechnych, w dziale VI - art. 231-254 ${ }^{6}$. Analiza tych przepisów nie pozwalała na mówienie o prokuraturze jako o organie niezależnym. Art. 231 wyżej wymienionego rozporządzenia przewidywał, że prokurator stoi na straży ustaw i w czynnościach swych podlega zleceniom swojego zwierzchnika. Ustawa przewidywała też, że prokuraturą kieruje Naczelny Prokurator, który był jednocześnie Ministrem Sprawiedliwości (art. $235 \S 1$ wymienionego rozporządzenia). Pierwotnie więc prokuratura była ukształtowana na zasadzie unii personalnej osoby kierującej prokuraturą i Ministra Sprawiedliwości.

Niezależność prokuratora była praktycznie minimalna w okresie PRL-u. Po II wojnie światowej pierwsza ustawa o prokuraturze z dnia 20 lipca 1950 r. nie przewidywała instytucji niezależności prokuratora, ale w art. 11 stanowiła, że

${ }^{5}$ L. Mazowiecka, op. cit., s. 214. Zob. S. Waltoś, Prokuratura-jej miejsce wśród organów władzy, struktura i funkcje, „Państwo i Prawo” 2002, z. 4, s. 8-9; S. Włodyka, Ustrój organów ochrony prawnej, Warszawa 1975, s. 232-239.

${ }^{6}$ Dz.U., nr 12, poz. 93. Zob. J. Gurgul, Prokurator w II Rzeczypospolitej..., s. 8-20.

${ }^{7}$ Dz.U., nr 38, poz. 346. Zob. J.S. Konic, Uwagi ogólne o umiejscowieniu prokuratury $w$ systemie organów państwowych, „Nowe Prawo” 1957, nr 11, s. 25-37; A. Lityński, O prokuraturze, prokuratorze i procedurze (1944-1950). Uwag kilka, [w:] Zasady procesu karnego wobec wyzwań współczesności. Księga ku czci Profesora Stanisława Waltosia, red. J. Czapska, A. Gaberle, A. Światłowski, A. Zoll, Warszawa 2000, s. 143-154; J. Smoleński, Prawno-ustrojowe problemy 
organy Generalnego Prokuratora RP są w sprawowaniu swych funkcji niezawisłe od jakichkolwiek władz lub organów terenowych i podlegają Generalnemu Prokuratorowi. Konstytucja PRL z dnia 22 lipca 1952 r. ${ }^{8}$ przewidywała natomiast, że organy prokuratury podlegają Prokuratorowi Generalnemu PRL i w sprawowaniu swych funkcji są niezależne od organów terenowych. Niezależność nie została zatem wyraźnie i konkretnie przewidziana przez ustawę z dnia 20 lipca 1950 r. o prokuraturze i przez to w doktrynie co do zasady nie mówiono o zasadzie niezależności ${ }^{9}$. Jednakże ustawa ta zrywała z unią personalną Generalnego Prokuratora i Ministra Sprawiedliwości. Na czele prokuratury stał bowiem Generalny Prokurator Rzeczypospolitej (art. 1 wyżej wymienionej ustawy), którego powoływała i odwoływała Rada Państwa (art. 5 ust. 1 wyżej wymienionej ustawy). „Generalny Prokurator Rzeczypospolitej i jego organa stanowiły Prokuraturę Rzeczypospolitej Polskiej” (art. 2 wyżej wymienionej ustawy) ${ }^{10}$. Ponadto art. 6 ust. 1 tej ustawy przewidywał, że Prokuratura RP podlegała Radzie Państwa i działała zgodnie z jej wytycznymi.

Ustawa o prokuraturze z dnia 20 lipca 1950 r. określiła cel i nadrzędne funkcje prokuratury, takie jak: ugruntowanie praworządności ludowej, ochrona mienia społecznego i ściganie przestępstw (art. 1 wyżej wymienionej ustawy). Ugruntowanie praworządności zostało wymienione w pierwszej kolejności, a zatem stało się nadrzędne w stosunku do pozostałych ${ }^{11}$. Jak zauważył S. Śliwiński, opisując ustrój prokuratury pod rządami ustawy z 1950 r., ,,prokuratura niebędąca władzą sądową, lecz władzą administracyjną, nie ma niezawisłości, nieusuwalności i nieprzenoszalności. Jest zorganizowana monokratycznie, tzn. decyduje wola jednego, inni zaś członkowie urzędu są tylko jego pomocnikami”'2.

prokuratury, „Państwo i Prawo” 1963, z. 1, s. 77-89; S. Śliwiński, Polski proces karny przed sqdem powszechnym. Zasady ogólne, Warszawa 1961, s. 170-174; W. Winawer, O miejsce prokuratury w systemie organów państwowych, „Nowe Prawo” 1957, nr 6, s. 14-25; G. Auscaler, O Prokuraturze Rzeczypospolitej Polskiej, „Wojskowy Przegląd Prawniczy” 1950, nr 2, s. 119-134; M. Łysko, Prokuratorski nadzór ogólny w Polsce w latach 1950-1967, Białystok 2006.

${ }^{8}$ Dz.U. z 1952 r., nr 33, poz. 232.

9 Zasady tej nie wyróżniał S. Śliwiński (op. cit., s. 172). Inaczej natomiast przyjmował L. Schaff, który art. 11 ustawy z dnia 20 lipca 1950 r. o prokuraturze wiązał z zasadą niezawisłości prokuratury od terenowych organów władzy państwowej. Zob. L. Schaff, Proces karny Polski Ludowej. Wykład zasad ogólnych, Warszawa 1953, s. 197-199.

10 Trafnie, komentując wymieniony przepis, podkreślił J. Smoleński, że jeżeli wyrażenie „i jego organa” ma dotyczyć poszczególnych prokuratorów podległych Prokuratorowi Generalnemu, to jest ono błędne, gdyż prokuratorzy mają swoje własne - wynikające z ustawy - kompetencje, są więc organami państwa, a ściślej - prokuratury, a nie Prokuratora Generalnego. Jeśli zaś w wyrażeniu tym chodzi jedynie o aparat wykonawczy Prokuratora Generalnego (tj. o pomocników działających w jego imieniu), to sformułowanie ustawy jest niepełne, gdyż pomija najistotniejszy - poza Prokuratorem Generalnym - składnik prokuratury, tzn. prokuratorów działających jako organy. Zob. J. Smoleński, Prawno-ustrojowe problemy..., s. 79.

${ }^{11}$ J. Bednarzak, Prokuratura w 35-leciu PRL, „Nowe Prawo” 1979, nr 9, s. 7.

${ }^{12}$ S. Śliwiński, op. cit., s. 171-172. 
Pierwszy raz o niezależności w prokuraturze stanowiła ustawa z dnia 14 kwietnia 1967 r. o Prokuraturze Polskiej Rzeczypospolitej Ludowej ${ }^{13}$. W art. 5 ust. 1 przewidywała krótko, że prokuratorzy są w sprawowaniu swoich funkcji niezależni od terenowych organów władzy oraz organów administracji państwowej i podlegają jedynie prokuratorom przełożonym ${ }^{14}$. Wskazany przepis mówił wyraźnie o niezależności prokuratora, jednak w aspekcie zewnętrznym (wobec innych organów państwa), a nie wobec przełożonych. Powinno się w związku $\mathrm{z}$ tym wymieniony artykuł odnosić do prokuratury, a nie do prokuratora ${ }^{15}$.

Jeżeli chodzi o organizację ustrojową prokuratury, to ustawa ta powielała w głównej mierze rozwiązania ustawy z 1950 r.

Nie zmieniała ona niczego w zakresie koncepcji prokuratury, jej klasowej istoty, ani w zakresie jej usytuowania wśród organów państwowych. Wprowadziła natomiast zmiany, które można by oceniać z punktu widzenia umocnienia pozycji prokuratora jako strażnika praworządności, pogłębienia integracji organów prokuratorskich, pogłębienia i rozszerzenia działalności profilaktycznej prokuratury, a także dokonała przeobrażenia tzw. nadzoru prokuratorskiego nad przestrzeganiem prawa i praworządności w prokuratorską kontrolę przestrzegania prawa ${ }^{16}$.

Prokurator Generalny był powoływany i odwoływany przez Radę Państwa (art. 7 ust. 1 wyżej wymienionej ustawy) oraz jednocześnie jej podlegał i działał zgodnie z jej wytycznymi (art. 4 ust. 1 wyżej wymienionej ustawy). Zestawienie tych przepisów z art. 5 ust. 1 prowadzi do wniosku, że prokuratura, w omawianym okresie, miała być tylko niezależna od organów miejscowych (terenowych) i organów administracji państwowej, ale nie od organu centralnego - Rady Państwa.

Na gruncie wymienionego art. 5 ust. 1 J. Smoleński podkreślił, że:

[...] zasady niezależności nie należy mylić z zasadą niezawisłości. Niezależność oznacza brak podporządkowania na zewnątrz, tj. wobec innych pionów organów państwowych; niezawisłość zaś polega na braku podległości zarówno w stosunkach zewnętrznych, jak i wewnętrznych. Niezawisły jest sędzia, gdyż podlega wyłącznie ustawie i nikt (nie wyłączając przełożonego) nie ma prawa wpływania na niego w zakresie wykonywania przezeń funkcji sędziowskich. Natomiast prokurator jest tylko niezależny. W stosunkach wewnętrznych bowiem obowiązuje w prokuraturze całkowite przeciwieństwo zasady niezawisłości właściwe sądownictwu, a mianowicie zasada hierarchicznego podporządkowania. W art. 5 ust. 1 stwierdza się, że „Prokuratorzy [...] w sprawowaniu swych funkcji [...] podlegają [...] prokuratorom przełożonym”, co oznacza, że służbowe polecenia przełożonych wiążą prokuratorów podległych i muszą być przez nich bezwzględnie wykonywane ${ }^{17}$.

${ }^{13}$ Dz.U., nr 13, poz. 55. Zob. J. Bednarzak, op. cit., s. 3-13; S. Kalinowski, Polski proces karny, Warszawa 1971, s. 206-218; J. Smoleński, Nowa ustawa o Prokuraturze PRL, „Państwo i Prawo" 1967, z. 8-9, s. 260-268; S. Waltoś, Karnoprocesowe konsekwencje nowej ustawy o prokuraturze, „Nowe Prawo” 1967, nr 9, s. 1111-1121; J. Stembrowicz, Prokuratura wedtug nowej ustawy. Zagadnienia wybrane, „Państwo i Prawo” 1968, z. 6, s. 928-942.

${ }_{14}$ Zob. H. Zięba, Organizacja i funkcje prokuratury PRL, Rzeszów 1984, s. 84-101, 122.

${ }^{15}$ W literaturze jednak, pod rządami ustawy o prokuraturze z 1967 r., nie wszyscy wyróżniali niezależność jako zasadę organizacyjną prokuratury. Zob. S. Kalinowski, op. cit., s. 207-208.

${ }^{16}$ J. Bednarzak, op. cit., s. 8.

17 J. Smoleński, Prokuratura Polskiej Rzeczypospolitej Ludowej. Komentarz do ustawy o pro- 
Kolejna ustawa o prokuraturze, z dnia 20 czerwca $1985 \mathrm{r}^{18}$, w początkowym kształcie przewidywała krótko, że prokuratorzy w sprawowaniu swych funkcji są niezależni i podlegają jedynie prokuratorom przełożonym (art. 10 u.o.p.). Następnie, od 27 marca 1991 r., zapisano, że prokurator przy wykonywaniu czynności określonych w ustawie jest niezależny, z uwzględnieniem granic niezależności określonych w ust. 2, który stanowił, że prokurator jest obowiązany wykonywać zarządzenia, wytyczne i polecenia przełożonego prokuratora. Jeżeli jednak polecenie dotyczyło treści czynności w postępowaniu, prokurator mógł żądać doręczenia mu polecenia na piśmie wraz z uzasadnieniem, zmiany polecenia lub wyłączenia go od wykonania tej czynności albo od udziału w sprawie. O wyłączeniu rozstrzygał ostatecznie prokurator bezpośrednio przełożony nad prokuratorem, który wydał polecenie (art. 8 ust. 1 i 2 u.o.p.). W przeciwieństwie do poprzedniego stanu prawnego ustawodawca, po raz pierwszy, odwoływał się do niezależności prokuratora wobec przełożonych (w aspekcie wewnętrznym), a nie - jak poprzednio - wobec innych jednostek organizacyjnych państwa.

Ustawa z dnia 29 grudnia 1989 r. o zmianie Konstytucji Polskiej Rzeczypospolitej Ludowej ${ }^{19}$ wprowadziła do Konstytucji Polskiej Rzeczypospolitej Ludowej (art. 64 ust. 2) zasadę unii personalnej Ministra Sprawiedliwości i Prokuratora Generalnego. W konsekwencji ustawą z dnia 22 marca 1990 r. o zmianie ustawy o Prokuraturze Polskiej Rzeczypospolitej Ludowej, Kodeksu postępowania w sprawach o wykroczenia oraz ustawy o Sądzie Najwyższym ${ }^{20}$ przetransportowano już do ustawy o prokuraturze (w art. 1 ust. 2) wymienioną zasadę konstytucyjną. Ustawa ta weszła w życie z dniem 31 marca $1990 \mathrm{r}$.

Istotną zmianę $\mathrm{w}$ omawianej problematyce przyniosła ustawa $\mathrm{z}$ dnia 10 maja 1996 r. o zmianie ustaw o prokuraturze, o Sądzie Najwyższym, o Trybunale Konstytucyjnym oraz ustawy - Prawo o ustroju sądów powszechnych i ustawy - Prawo o adwokaturze ${ }^{21}$, która przewidywała, że prokurator jest obowiązany wykonywać zarządzenia, wytyczne i polecenia przełożonego prokuratora. Polecenie dotyczące treści czynności procesowej prokurator przełożony miał wydawać na piśmie, a na żądanie prokuratora - wraz z uzasadnieniem. W razie przeszkody w doręczeniu polecenia $\mathrm{w}$ formie pisemnej dopuszczalne było przekazanie polecenia ustnie, $\mathrm{z}$ tym że przełożony był obowiązany niezwłocznie potwierdzić je na piśmie (art. 8 ust. 2); jeżeli prokurator nie zgadzał się z poleceniem, mógł żądać zmiany polecenia lub wyłączenia go od wykonywania czynności albo od udziału w sprawie. O wyłączeniu rozstrzygał ostatecznie prokurator bezpośrednio przełożony nad prokuratorem,

kuraturze PRL i innych przepisów dotyczacych prokuratury, Warszawa 1981, s. 35. Zob. S. Włodyka, Ustrój organów ochrony prawnej, Warszawa 1968, s. 209, 241.

${ }^{18}$ Dz.U. z 1985 r., nr 31, poz. 138, dalej jako: u.o.p.

${ }_{19}$ Dz.U., nr 75, poz. 444.

${ }^{20}$ Dz.U., nr 20, poz. 121.

${ }^{21}$ Dz.U., nr 77, poz. 367. 
który wydał polecenie, chyba że wydał je Prokurator Generalny (art. 8 ust. 3). Żądanie, o którym mowa, prokurator zgłaszał na piśmie wraz z uzasadnieniem przełożonemu, który wydał polecenie (art. 8 ust. 4). Polecenie dotyczące treści czynności procesowej, wydane przez prokuratora przełożonego innego niż prokurator bezpośrednio przełożony, nie mogło obejmować sposobu zakończenia postępowania przygotowawczego i postępowania przed sądem (art. 8 ust. 5).

Jak podkreślił W. Grzeszczyk:

[...] powyższe rozwiązanie, zawarte w art. 8 ust. 5 u.o.p., w sposób istotny poszerza zakres samodzielności prokuratora przy wykonywaniu czynności procesowej. Uregulowanie to należy rozumieć w ten sposób, iż polecenie co do sposobu zakończenia postępowania przygotowawczego i postępowania przed sądem może wydać tylko prokurator bezpośrednio przełożony, a więc kierownik danej jednostki organizacyjnej. Prokurator przełożony nadrzędny (np. prokurator wojewódzki wobec prokuratora prokuratury rejonowej) nie jest uprawniony do wydania takiego polecenia, jak również nie może - na zasadzie hierarchicznego podporządkowania - zlecić podległemu kierownikowi jednostki, aby ten, jako bezpośrednio przełożony, wydał takie polecenie, chyba że - co w praktyce występuje rzadko - czynności procesowej dokonuje kierownik jednostki, np. prokurator rejonowy ${ }^{22}$.

Taki stan prawny trwał $\mathrm{z}$ niewielkimi zmianami praktycznie do 31 marca 2010 r., tj. do wejścia w życie ustawy z dnia 9 października 2009 r. o zmianie ustawy o prokuraturze oraz niektórych innych ustaw ${ }^{23}$. Głównym celem tej nowelizacji było rozdzielenie funkcji Prokuratora Generalnego i Ministra Sprawiedliwości. Ustawa ta w sposób istotny zmieniła też regulacje dotyczące zależności prokuratora od swoich przełożonych.

W art. 8 ust. 1 zostało przewidziane, że prokurator przy wykonywaniu czynności określonych w ustawach jest niezależny, z zastrzeżeniem przepisów ust. 2 oraz art. 8a i 8b. Prokurator był obowiązany wykonywać zarządzenia, wytyczne i polecenia przełożonego prokuratora. Zarządzenia, wytyczne i polecenia nie mogły dotyczyć treści czynności procesowej (art. 8 ust. 2). Prokurator bezpośrednio przełożony był uprawniony do zmiany lub uchylenia decyzji prokuratora podległego. Zmiana lub uchylenie decyzji wymagała formy pisemnej i była włączana do akt sprawy (art. 8a). Prokurator przełożony mógł powierzyć podległym prokuratorom wykonywanie czynności należących do jego zakresu działania, chyba że ustawa zastrzegała określoną czynność wyłącznie do jego właściwości. Prokurator przełożony mógł także przejmować sprawy prowadzone przez prokuratorów podległych i wykonywać ich czynności (art. 8b).

Powyższa ustawa wprowadziła więc niezależność zewnętrzną prokuratury (przez rozdzielenie funkcji Ministra Sprawiedliwości i Prokuratora Generalnego) oraz - w bardzo szerokim zakresie - niezależność wewnętrzną. W porównaniu

${ }^{22}$ W. Grzeszczyk, Nowy kształt ustawy o prokuraturze, [w:] Prokuratura, ustawa, regulamin, inne przepisy, red. W. Czerwiński, Toruń 1997, s. 36-37.

${ }^{23}$ Dz.U., nr 178, poz. 1375. 
z poprzednim stanem prawnym $\mathrm{w}$ istotny sposób zmodyfikowała ona funkcjonowanie prokuratury.

Według nowej ustawy, z dnia 28 stycznia 2016 r. - Prawo o prokuraturze, kwestia niezależności prokuratury powraca do stanu prawnego sprzed 31 marca 2010 r., a w pewnej części nawet sprzed 1996 r. Nadal na czele prokuratury będzie stał Prokurator Generalny, lecz każdorazowo musi to być Minister Sprawiedliwości (art. $1 \S 2$ p.o.p.). Nowością jest, że Minister Sprawiedliwości (Prokurator Generalny) będzie musiał posiadać wyłącznie obywatelstwo polskie, korzystać z pełni praw cywilnych i obywatelskich, nie może być prawomocnie skazany za przestępstwa ścigane z oskarżenia publicznego oraz musi posiadać nieskazitelny charakter i wykształcenie prawnicze (art. 1 § zd. 2 w zw. z art. 75 § 1 pkt 1-3 i 8 p.o.p.). Ustawa ta przywróciła instytucję Prokuratury Krajowej i Prokuratora Krajowego. Ponadto według niej zamiast prokuratur apelacyjnych będą funkcjonowały prokuratury regionalne (art. $1 \S 3$ p.o.p.). Zlikwidowany został również szczebel prokuratur wojskowych, zamiast których utworzono wewnętrzne komórki wojskowe w powszechnych jednostkach organizacyjnych prokuratury (zob. art. $3 \S 2-6$ p.o.p.). Wydziały do Spraw Przestępczości Zorganizowanej i Korupcji, dotychczas funkcjonujące w Prokuraturach Apelacyjnych, zostały przemianowane na wydziały zamiejscowe Prokuratury Krajowej (art. $20 \S 1$ p.o.p.).

Art. $1 \S 1$ p.o.p. przewiduje, że prokuraturę stanowią: Prokurator Generalny, Prokurator Krajowy, pozostali zastępcy Prokuratora Generalnego oraz prokuratorzy powszechnych jednostek organizacyjnych prokuratury i prokuratorzy Instytutu Pamięci Narodowej - Komisji Ścigania Zbrodni Przeciwko Narodowi Polskiemu. Prokuratorami powszechnych jednostek organizacyjnych prokuratury są natomiast prokuratorzy Prokuratury Krajowej, prokuratur regionalnych, prokuratur okręgowych i prokuratur rejonowych (art. $1 \S 3$ i art. 16 p.o.p.). W ten sposób prokuratura ponownie przestaje być organem niezależnym w aspekcie zewnętrznym, ponieważ będzie nią kierował polityk - Minister Sprawiedliwości.

W uzasadnieniu do wymienionej ustawy podkreślono, że:

[...] kolejna nowelizacja ustawy o prokuraturze, przeprowadzona w 2009 r., doprowadziła do rozdzielenia stanowiska Prokuratora Generalnego od stanowiska Ministra Sprawiedliwości, co w opinii wielu przedstawicieli doktryny, stanowić mogło naruszenie art. 146 ust. 4 pkt 9 Konstytucji. Jedną z podstawowych funkcji państwa i jednocześnie obowiązków rządu jest zapewnienie bezpieczeństwa wewnętrznego i porządku publicznego. Niezwykle istotny element $\mathrm{w}$ realizacji tego zobowiązania stanowi prokuratura. Powołaną wyżej nowelizacją bardzo poważnie ograniczono zatem Radzie Ministrów realizację konstytucyjnych zobowiązań wobec państwa, związanych z zapewnieniem bezpieczeństwa jego obywatelom. Model funkcjonowania prokuratury obowiązujący od 1 kwietnia 2010 r. w dość powszechnym odczuciu społecznym, ale także w opinii ekspertów, nie zdał egzaminu. Jednym z głównych powodów tego stanu rzeczy były regulacje prawne niezwykle ograniczające pozycję Prokuratora Generalnego i to zarówno w aspekcie wewnętrznym, jak i zewnętrznym ${ }^{24}$.

${ }^{24}$ Uzasadnienie Druku Sejmowego nr 162 Sejmu VIII kadencji. W uzasadnieniu do wymie- 
Wymieniona argumentacja jest od dawna standardowym uzasadnieniem stosowanym przy próbie popierania postulatu połączenia funkcji Ministra Sprawiedliwości i Prokuratora Generalnego. Jak trafnie zaznaczył A. Herzog:

[...] prokuratura nie jest bowiem organem realizującym zadania państwa w zakresie bezpieczeństwa wewnętrznego i porządku publicznego. Jak wskazuje się w doktrynie, realizacja zadań w zakresie zapewnienia zewnętrznego i wewnętrznego bezpieczeństwa państwa podejmowana jest przez ministrów: spraw zagranicznych, obrony narodowej oraz spraw wewnętrznych i administracji, którzy działają w myśl wytycznych udzielanych przez Radę Ministrów [...]. Żaden przepis prawa nie określa zaś, iż do zadań prokuratury należą sprawy „bezpieczeństwa i porządku publicznego" [...]. Dodać należy, że ta kategoria spraw zgodnie z ustawą z dnia 24 maja $2002 \mathrm{r}$. o Agencji Bezpieczeństwa Wewnętrznego oraz Agencji Wywiadu przeznaczona została właśnie Agencji Bezpieczeństwa Wewnętrznego. Rada Ministrów dysponuje zatem określonymi ustawowo i wystarczającymi instrumentami dla zapewnienia „bezpieczeństwa wewnętrznego i porządku publicznego", zaś prokuratura nie jest organem do tego przeznaczonym ${ }^{25}$.

Z wymienioną argumentacją A. Herzoga należy się w całości zgodzić. Przypisywanie prokuraturze zadania $\mathrm{w}$ zakresie bezpieczeństwa wewnętrznego i porządku publicznego jest mylące i niezrozumiałe. Co więcej, sama ustawa - Prawo o prokuraturze w żadnym przepisie nie stanowi o wyżej wymienionej zasadzie, a wręcz przeciwnie - przewiduje, że ,prokuratura wykonuje zadania w tylko w zakresie ścigania przestępstw oraz stania na straży praworządności” (art. 2 p.o.p. $)^{26}$. Ustawa z dnia 24 maja 2002 r. o Agencji Bezpieczeństwa Wewnętrznego i Agencji Wywiadu ${ }^{27}$ stanowi natomiast w art. 1, że Agencja Bezpieczeństwa Wewnętrznego jest właściwa w sprawach ochrony bezpieczeństwa wewnętrznego państwa i jego porządku konstytucyjnego (zob. także art. 5 ust. 1 wymienionej ustawy). Podobnie ustawa z dnia 6 kwietnia 1990 r. o Policji ${ }^{28}$ w art. 1 ust. 1 zaznacza, że do ochrony bezpieczeństwa ludzi oraz do utrzymania bezpieczeństwa i porządku publicznego przeznaczona jest Policja.

Nowa ustawa - Prawo o prokuraturze w sposób istotny zwiększa również uprawnienia Prokuratora Generalnego (Ministra Sprawiedliwości). Ustawa wyraźnie przewiduje, że Prokurator Generalny należy do prokuratury (art. $1 \S 1$ p.o.p.), jest jej naczelnym organem (art. $1 \S 2$ zd. 1 p.o.p.) i kieruje działalnością prokuratury osobiście lub za pośrednictwem Prokuratora Krajowego oraz pozostałych zastępców Prokuratora Generalnego (art. $13 \S 1$ p.o.p.). Jednocześnie

nionego projektu ustawy błędnie powołano art. 146 ust. 4 pkt 9 Konstytucji zamiast art. 146 ust. 4 pkt 7.

${ }^{25}$ A. Herzog, Niezależność prokuratury - mit czy nadzieja?, „Prokuratura i Prawo” 2009, nr 1 , s. 118.

${ }^{26}$ Cechą charakterystyczną jest to, że ściganie przestępstw jest wymienione obecnie w pierwszym rzędzie, a w drugim - stanie na straży praworządności. W poprzednim stanie prawnym te dwa elementy zadań prokuratury były zapisane w odwrotnej kolejności.

${ }^{27}$ Dz.U. z 2010 r., nr 29, poz. 154 z późn. zm.

${ }^{28}$ Dz.U. z 2015 r., poz. 359 z późn. zm. 
Prokuratura Krajowa, kierowana przez Prokuratora Krajowego, ma za zadanie zapewnić obsługę Prokuratora Generalnego i Krajowego (art. $17 \S 1$, art. $18 \S 1$ p.o.p.). Na wniosek Prokuratora Krajowego Prokurator Generalny powołuje i odwołuje prokuratorów regionalnych, okręgowych i rejonowych (art. $15 \S 1$ p.o.p.), którzy nie będą już pełnić swych funkcji kadencyjnie. Poza tym Prokurator Generalny powołuje $\mathrm{w}$ powszechnych jednostkach organizacyjnych prokuratury kandydatów na stanowiska prokuratorskie, którzy składają przed nim ślubowanie (art. $74 \S 1$, art. $92 \S 1$ p.o.p.).

Minister Sprawiedliwości (Prokurator Generalny) posiada także uprawnienia, które w przeszłości były wykorzystywane do wymuszania określonego postępowania na podległych prokuratorach. W szczególności mowa tu o prawie Prokuratora Generalnego do delegowania prokuratora powszechnych jednostek organizacyjnych prokuratury do innej jednostki na okres do 6 miesięcy, nawet bez jego zgody, a w uzasadnionych przypadkach - z uwagi na potrzeby kadrowe - na okres do 12 miesięcy w ciągu roku (art. $106 \S 2$ i 3 p.o.p. $)^{29}$.

Istotne są też uprawnienia Prokuratora Generalnego w postępowaniu dyscyplinarnym. Powołuje on rzecznika dyscyplinarnego (art. $153 \S 1$ zd. 2 p.o.p.), może go w pewnych warunkach odwołać (art. 153 § 4 p.o.p.) i jest on obowiązany podejmować czynności na każde jego żądanie (art. 154 § 1 p.o.p.). Ponadto Prokurator Generalny powołuje przewodniczącego i zastępcę przewodniczącego sądu dyscyplinarnego (art. $145 \S 2$ p.o.p.).

Prokurator Generalny jest tzw. prokuratorem dyscyplinarnym (art. 144 p.o.p.), a to oznacza, że ma np. prawo do zawieszenia prokuratora na okres do 6 miesięcy w czynnościach, jeżeli z uwagi na charakter przewinienia dyscyplinarnego konieczne jest natychmiastowe odsunięcie go od wykonywania obowiązków (art. 150 i 151 p.o.p.). Prokurator Generalny ma również prawo wglądu w czynności sądów dyscyplinarnych, może zwracać uwagę na stwierdzone uchybienia, żądać wyjaśnień oraz usunięcia skutków uchybienia, z tym zastrzeżeniem, że czynności te nie mogą wkraczać w dziedzinę, w której członkowie sądów dyscyplinarnych są niezawiśli (art. 169 p.o.p.).

Prokurator Generalny posiada szereg uprawnień wpływających na bieg postępowania przygotowawczego i sposób funkcjonowania prokuratury. Większość $\mathrm{z}$ nich jest związana $\mathrm{z}$ faktem, że Prokurator Generalny według nowej ustawy jest prokuratorem przełożonym wobec każdego innego podległego mu prokuratora (art. $13 \S 2$ p.o.p.). Tytułem przykładu można wymienić jego prawo do:

- wydawania zarządzeń, wytycznych i poleceń (art. $13 \S 2$ w zw. z art. 34 $\S 1$ p.o.p.),

- zmiany lub uchylenia decyzji prokuratora podległego (art. 8 w zw. z art. 13 $\S 2$ p.o.p.),

${ }^{29}$ Przepis ten jest odpowiednikiem art. 50 ust. 1 i la u.o.p. w wersji sprzed 31 marca $2010 \mathrm{r}$. 
- stosowania zasady substytucji i dewolucji (art. 9 § 1 i 2 w zw. z art. $13 \S 2$ p.o.p.),

- zwrócenia prokuratorowi uwagi na piśmie na zasadach określonych w art. 139 p.o.p. w przypadku, gdy dopuścił się on istotnego uchybienia w zakresie sprawności postępowania przygotowawczego (art. $7 \S 7$ pkt 1 w zw. z art. $13 \S 2$ p.o.p.),

- wytknięcia prokuratorowi uchybienia w trybie art. 140 p.o.p. w przypadku, gdy dopuścił się on oczywistej obrazy przepisów prawa przy prowadzeniu sprawy (art. $7 \S 7$ pkt 2 w zw. art. $13 \S 2$ p.o.p.),

- żądania wszczęcia postępowania dyscyplinarnego w przypadku, gdy prokurator dopuścił się oczywistej i rażącej obrazy przepisów (art. 7 § 8 w zw. z art. 13 $\S 2$ p.o.p.),

- wymierzenia kary porządkowej upomnienia za przewinienia mniejszej wagi (art. $149 \S 1 \mathrm{w}$ zw. z art. $13 \S 2$ p.o.p.),

- przekazywania mediom informacji z toczącego się postępowania przygotowawczego, nawet bez zgody prokuratora prowadzącego (art. $12 \S 2$ i 3 p.o.p.),

- kontroli czynności operacyjno-rozpoznawczych i polecenia ich przeprowadzenia (art. $57 \S 2$ i 3 p.o.p.),

- zarządzenia, aby dane postępowanie przygotowawcze było prowadzone w Prokuraturze Krajowej, nawet niezależnie od właściwości ogólnej (art. 63 § 2 p.o.p.).

Taka organizacja prokuratury jest swego rodzaju ewenementem ustrojowym, ponieważ prokuratorzy, którzy nie mogą należeć do partii politycznych i brać udziału w żadnej działalności politycznej (art. 97 § 1 p.o.p.), będą kierowani i będą mieli obowiązek wykonywania poleceń Ministra Sprawiedliwości (czyli najczęściej polityka), a ten powinien działać zgodnie z kierunkiem Prezesa Rady Ministrów i konkretnej partii politycznej. Siłą rzeczy takie powiązanie powoduje, że prokuratura będzie wciągana w spory polityczne prowadzone przez Ministra Sprawiedliwości i każda decyzja prokuratora, wydana na polecenie Prokuratora Generalnego, może spotkać się z zarzutem, że ma zabarwienie polityczne.

Poza tym należy ponownie przeciwstawić sobie pojęcie „prokuratura” z określeniem ,prokurator”, ponieważ nie są to określenia tożsame. Do prokuratury należy bowiem Prokurator Generalny (wynika to z treści m.in. art. 1 § 1 i 2 p.o.p.), który nie jest jednocześnie prokuratorem ${ }^{30}$. Może on wydać polecenie dokonania przez danego prokuratora każdej czynności procesowej, ale nie może sam prowadzić np. postępowania przygotowawczego. Co więcej, każdy prokurator jest obowiązany do podejmowania działań określonych w ustawach, kierując się zasadą bezstronności

${ }^{30}$ Nie należy on do powszechnych jednostek organizacyjnych prokuratury (art. $1 \S 3$ i art. 16 p.o.p.) ani do Instytutu Pamięci Narodowej (art. $1 \S 4$ p.o.p.). Oznacza to, że nie musi mieć wszystkich kwalifikacji do zajmowania stanowiska prokuratora, poza tym nie wiążą go ograniczenia i przywileje związane ze statusem prokuratora. Nowością w nowej ustawie jest wyraźne przyznanie Prokuratorowi Generalnego immunitetu formalnego (art. $135 \S 1$ i 15 p.o.p.). 
i równego traktowania wszystkich obywateli (art. 6 p.o.p., art. 4 k.p.k.), ale wymóg ten nie odnosi się do Prokuratora Generalnego (Ministra Sprawiedliwości).

Kwestia tego, że Prokurator Generalny nie ma prawnych możliwości prowadzenia postępowania przygotowawczego wydaje się oczywista, jednak z treści art. 2 i $3 \S 1$ pkt 1 p.o.p. wypływa norma wręcz przeciwna. Pierwszy z tych przepisów stanowi, że prokuratura wykonuje zadania w zakresie ścigania przestępstw oraz stania na straży praworządności. Artykuł ten odnosi się do prokuratury (a więc i do Prokuratora Generalnego), a nie do prokuratora. Art. 3 $\S 1$ pkt 1 p.o.p. można natomiast odczytać w ten sposób, że zadania w zakresie ścigania przestępstw oraz stania na straży praworządności wykonuje Prokurator Generalny przez prowadzenie lub nadzorowanie postępowania przygotowawczego w sprawach karnych. Zadania i sposób ich realizacji odnoszą się zatem do prokuratury, a nie do prokuratora. W związku z tym, co już podkreślono, że nie są to pojęcia tożsame, należy dojść do wniosku, że Prokurator Generalny, który nie jest prokuratorem, może prowadzić osobiście postępowanie przygotowawcze i dokonywać czynności procesowych na tym etapie procesu karnego.

Prokurator Generalny posiada też pewne funkcje szczególne, które są związane tylko z rolą, jaką pełni ${ }^{31}$. Pomimo tego, że nie jest on prokuratorem, to jednak według nowej ustawy jest:

- prokuratorem przełożonym wobec każdego prokuratora powszechnych jednostek organizacyjnych prokuratury oraz prokuratorów Instytutu Pamięci Narodowej (art. 13 § 2 p.o.p.),

- prokuratorem bezpośrednio przełożonym wobec Prokuratora Krajowego, pozostałych zastępców Prokuratora Generalnego i zastępcy Prokuratora Krajowego (art. 31 § 1 p.o.p.),

- przełożonym dyscyplinarnym $\mathrm{w}$ stosunku do każdego prokuratora powszechnych jednostek organizacyjnych prokuratury (art. 144 p.o.p.).

W związku z powyższym można się zastanawiać, czy takie ukształtowanie prokuratury nie jest obejściem przepisu Konstytucji przewidującego, że stanowiska posła i senatora nie można łączyć z funkcją prokuratora (art. 103 ust. 2, art. 108 Konstytucji RP). Minister Sprawiedliwości, który obejmuje z mocy ustawy funkcję Prokuratora Generalnego, pomimo tego, że nie musi mieć kwalifikacji do zajmowania stanowiska prokuratora i nie jest nim w sensie formalnym, to jednak należy do prokuratury jako jednostki organizacyjnej oraz ma praktycznie nieograniczone prawo ingerowania w pracę prokuratorów. Celem art. 103 Konstytucji RP jest, aby pewne stanowiska organów państwa nie były obejmowane przez polityków, a przez to, by nie zostały one upolitycznione. Taka sytuacja może zaistnieć oczywiście, gdy dany podmiot (polityk) może wpływać na pracę innego urzędu, dlatego art. 103 Konstytucji powinno się bardzo szeroko wykładać,

${ }^{31}$ Zob. np. art. 328 k.p.k., art. 521 § 1 k.p.k., art. 567 k.p.k. 
w sensie funkcjonalnym i gwarancyjnym, tak aby przez skomplikowane i fikcyjne regulacje ustrojowe nie doprowadzić do próby jego obejścia. Gwarancją niezależności (zewnętrznej) danego organu państwa jest niepołączalność pewnych funkcji (tzw. incompatibilitas). Inaczej mówiąc, w art. 103 Konstytucji chodzi o to, aby podmioty w nim wymienione były niezależne w sensie zewnętrznym. Połączenie funkcji Ministra Sprawiedliwości i Prokuratora Generalnego tę normę konstytucyjną łamie.

Jeżeli chodzi o niezależność prokuratora wobec przełożonych (w aspekcie wewnętrznym), to również ta kwestia została w sposób istotny pogorszona w porównaniu z poprzednim stanem prawnym. Co prawda, dalej ustawa przewiduje w art. 7 p.o.p., że prokurator przy wykonywaniu swoich czynności określonych w ustawach jest niezależny, ale z zastrzeżeniami określonymi w art. 7 § 2-6 oraz art. 8 i 9 p.o.p. Prokurator jest obowiązany wykonywać zarządzenia, wytyczne i polecenia przełożonego prokuratora (art. $7 \S 2$ p.o.p.). Polecenie dotyczące treści czynności procesowej prokurator przełożony wydaje na piśmie, a na żądanie prokuratora - wraz z uzasadnieniem. W razie przeszkody w doręczeniu polecenia $\mathrm{w}$ formie pisemnej dopuszczalne jest przekazanie polecenia ustnie, z tym że przełożony jest obowiązany niezwłocznie potwierdzić je na piśmie. Polecenie włącza się do akt podręcznych sprawy (art. $7 \S 3$ p.o.p.). Jeżeli prokurator nie zgadza się z poleceniem dotyczącym treści czynności procesowej, może żądać zmiany polecenia lub wyłączenia go od wykonania czynności albo od udziału w sprawie. O wyłączeniu rozstrzyga ostatecznie prokurator bezpośrednio przełożony nad prokuratorem, który wydał polecenie (art. $7 \S 4$ p.o.p.).

Zasada substytucji i dewolucji pozostała natomiast niezmieniona (art. 9 p.o.p.). Ustawodawca nadal nie wyjaśnia, co rozumie pod pojęciami „zarządzenia”, „wytyczne” i „polecenia”. Niewątpliwie ich wspólną cechą jest to, że są władczą formą ograniczenia niezależności prokuratury.

Zarządzenia, wytyczne i polecenia może wydawać tylko prokurator przełożony (art. $7 \S 2$ p.o.p.). Ponadto ustawa odrębnie stanowi, że prawo wydawania wytycznych, zarządzeń i poleceń przysługuje także Prokuratorowi Generalnemu (art. $13 \S 1$ p.o.p.). Nowością jest to, że w Prokuraturze Krajowej będzie funkcjonowała baza wytycznych i zarządzeń Prokuratora Generalnego (art. 17 § 2 in fine p.o.p.).

Wytyczne w głównej mierze służą ujednoliceniu praktyki, usunięciu pojawiających się w niej nieprawidłowości oraz realizacji obowiązku strzeżenia praworządności. Mają one na celu wskazywanie prawidłowej metodyki prowadzenia postępowania przygotowawczego, co wyraźnie przewiduje już art. $60 \S 1$ p.o.p. Nie dotyczą one najczęściej konkretnej sprawy i mają charakter ogólny.

Nadal ustawa stanowi, że wytyczne Prokuratora Generalnego, wydane na wniosek Prokuratora Krajowego, dotyczące metodyki prowadzenia postępowania przygotowawczego są wiążące dla wszystkich organów uprawnionych do prowadzenia postępowania przygotowawczego (art. 60 § 1 p.o.p.), a więc nie tyl- 
ko dla prokuratury, ale też np. dla Policji, Centralnego Biura Antykorupcyjnego, Agencji Bezpieczeństwa Wewnętrznego.

Z kolei zarządzenia w praktyce prokuratorskiej odnoszą się najczęściej do kwestii organizacyjnych, np. podziału czynności prokuratorów, zastępowania w pracy, pełnienia dyżurów. Wymienione zarządzenia nie są nakierowanie na kwestie sposobu prowadzenia postępowania przygotowawczego. Mają one charakter stały, ogólny (zazwyczaj nie są skierowane do konkretnej sprawy) i administracyjny. Od zarządzeń organizacyjnych jako wewnętrznych regulacji prokuratury należy odróżnić zarządzenia procesowe wydawane $\mathrm{w}$ toku prowadzonych czynności przez prokuratora (zob. art. 93 § 3 k.p.k.).

Polecenia, w porównaniu z wytycznymi i zarządzeniami, są najbardziej władczą formą wkraczania w niezależność prokuratora i najczęściej odnoszą się do konkretnej sprawy. Prawo wydawania poleceń mają na gruncie nowej ustawy dwie grupy podmiotów: prokuratorzy przełożeni i prokuratorzy wymienieni dodatkowo w art. $34 \S 1$ p.o.p. ${ }^{32}$

Z kolei prokuratorem przełożonym jest:

1. Prokurator Generalny wobec prokuratorów powszechnych jednostek organizacyjnych prokuratury oraz prokuratorów Instytutu Pamięci Narodowej (art. $13 \S 2$ p.o.p.).

2. Prokurator Krajowy wobec prokuratorów Prokuratury Krajowej oraz prokuratorów pozostałych powszechnych jednostek organizacyjnych prokuratury (art. $18 \S 2$ p.o.p.).

3. Naczelnik Wydziału Zamiejscowego Departamentu do Spraw Przestępczości Zorganizowanej i Korupcji Prokuratury Krajowej wobec prokuratorów prokuratury regionalnej, prokuratorów prokuratury okręgowej oraz prokuratorów prokuratur rejonowych wykonujących swoje obowiązki w tym wydziale (art. 21 § 2 p.o.p.).

4. Prokurator regionalny wobec prokuratorów prokuratury regionalnej, prokuratorów prokuratury okręgowej oraz prokuratorów prokuratur rejonowych na obszarze działania prokuratury regionalnej (art. $22 \S 4$ p.o.p.).

5. Prokurator okręgowy wobec prokuratorów prokuratury okręgowej oraz prokuratorów rejonowych i prokuratorów prokuratur rejonowych na obszarze działania prokuratury okręgowej (art. $23 \S 4$ p.o.p.).

6. Prokurator rejonowy wobec prokuratorów wykonujących czynności w tej jednostce (art. $24 \S 4$ p.o.p.).

Co do drugiej grupy podmiotów mających prawo wydawania poleceń $\mathrm{z}$ art. $34 \S 1$ p.o.p., to są to następujące osoby w zakresie zleconych im czynności:

1. Dyrektor departamentu Prokuratury Krajowej-w stosunku do podległych prokuratorów pełniących czynności w tych departamentach oraz prokuratorów regionalnych, okręgowych i rejonowych.

${ }^{32}$ Przepis ten jest odpowiednikiem art. 17a ust. 1 ustawy z dnia 20 czerwca 1985 r. o prokuraturze w stanie prawnym sprzed 31 marca $2010 \mathrm{r}$. 
2. Naczelnik wydziału w departamencie Prokuratury Krajowej-w stosunku do prokuratorów pełniących czynności w tych wydziałach.

3. Naczelnik wydziału i kierownik działu oraz samodzielnego działu prokuratury regionalnej - w stosunku do prokuratorów pełniących czynności $\mathrm{w}$ tych wydziałach, działach i samodzielnych działach oraz prokuratorów okręgowych i rejonowych.

4. Naczelnik wydziału oraz kierownik działu, samodzielnego działu i ośrodka zamiejscowego prokuratury okręgowej - w stosunku do prokuratorów pełniących czynności w tych wydziałach, działach, samodzielnych działach i ośrodkach zamiejscowych oraz prokuratorów rejonowych.

5. Kierownik ośrodka zamiejscowego prokuratury rejonowej - w stosunku do prokuratorów pełniących czynności w tym ośrodku.

Powyższe pokazuje, że prawo wydawania poleceń ma bardzo szeroka grupa podmiotów. Praktycznie każda osoba będąca zwierzchnikiem służbowym ma prawo do wydawania poleceń swoim podwładnym.

Ponadto nowa ustawa przewiduje, że prokurator przełożony jest uprawniony do zmiany lub uchylenia decyzji prokuratora podległego. Zmiana lub uchylenie decyzji wymaga formy pisemnej i jest włączana do akt podręcznych sprawy. Zmiana lub uchylenie decyzji doręczonej stronom, ich pełnomocnikom lub obrońcom oraz innym uprawnionym podmiotom może nastąpić wyłącznie z zachowaniem trybu i zasad określonych w ustawie (art. 8 § 1 i 2 p.o.p.).

Obecnie nie ustanowiono nawet, tak jak w stanie prawnym sprzed 31 marca 2010 r., że jeżeli polecenie dotyczy treści czynności procesowej wydanej przez prokuratora przełożonego innego niż bezpośrednio przełożony, nie może ono obejmować sposobu zakończenia postępowania przygotowawczego i postępowania przed sądem. Brak takiego zastrzeżenia w nowej ustawie powoduje bardzo istotne ograniczenie niezależności prokuratora. Obecnie prokuratorzy przełożeni i inne podmioty mają bowiem uprawnienie nieograniczonego ingerowania w czynności procesowe prokuratorów podległych. Mogą zatem polecić dokonanie każdego rodzaju czynności w danej sprawie, w tym dotyczącej sposobu zakończenia postępowania przygotowawczego. W istocie rzeczy jest to cofnięcie się do stanu prawnego sprzed $1996 \mathrm{r}$.

Polecenia można podzielić na dwie grupy: dotyczące treści czynności procesowej i takie, które ich nie dotyczą. Pierwsze muszą być wydawane na piśmie i są włączane do akt podręcznych sprawy. Drugie natomiast mogą mieć formę ustną i w praktyce dotyczą np. obowiązku brania przez prokuratora udziału w posiedzeniu sądu, udziału w czynności dowodowej itp. Co istotne, ustawa nie zastrzega, tak jak w poprzednim stanie prawnym (zob. art. 10 ust. 1 i 2 u.o.p.), że zarządzenia, wytyczne i polecenia Prokuratora Generalnego nie mogą dotyczyć treści czynności procesowych. Może on wobec tego wydać polecenie danemu prokuratorowi np. w kwestii sposobu zakończenia postępowania przygotowawczego. 
Iluzoryczną gwarancją zachowania niezależności przez prokuratora, gdy się nie zgadza z treścią polecenia, jest jego prawo do żądania:

- zmiany polecenia,

- wyłączenia go od wykonania czynności,

- wyłączenia go od udziału w sprawie ${ }^{33}$.

Jednakże o tych żądaniach prokuratora poległego będzie decydował prokurator bezpośrednio przełożony ${ }^{34}$ nad prokuratorem, który wydał polecenie. Ustawodawca pozostawia całkowitą swobodę prokuratorowi bezpośrednio przełożonemu w decydowaniu o zmianie polecenia czy wyłączeniu danej osoby od wykonania czynności. Nie precyzuje, czym ma się kierować, rozstrzygając taki spór między prokuratorem podległym a przełożonym. W istocie rzeczy może to powodować, iż regulacja ta nie będzie miała istotnego i praktycznego znaczenia. Co więcej, analiza art. 7 i 8 p.o.p. pozwala wyciągnąć wniosek, że wymienione uprawnienia służą prokuratorowi, któremu wydano polecenie, jeżeli jednak prokurator przełożony zmieni lub uchyli już wydaną decyzję prokuratora podległego, to nie dysponuje on jakąkolwiek formą sprzeciwu.

Ograniczona niezależność z art. 7 ust. 1 ustawy - Prawo o prokuraturze dotyczy wszystkich form prowadzonych postępowań przygotowawczych w szerokim tego słowa znaczeniu (śledztw, dochodzeń, czynności wyjaśniających w sprawach o wykroczenia, postępowaniach w sprawach cywilnych, administracyjnych itp.). Pozostaje jednak istotne pytanie, czy dotyczy także postępowania sądowego. Co do zasady na rozprawie przed sądem prokurator nie podejmuje merytorycznych decyzji procesowych, ale najczęściej składa wnioski i zajmuje stanowisko procesowe (czyli składa oświadczenia woli). Nie jest możliwe, aby bezpośrednio przełożony na tym etapie uchylał składane przez podległego prokuratora wnioski i oświadczenia. Jednakże nie ma żadnych przeszkód prawnych, aby wydać danemu prokuratorowi polecenie zajęcia określonego stanowiska $\mathrm{w}$ toku rozprawy czy np. złożenia wniosku o określony wymiar kary.

$Z$ drugiej strony należy zwrócić uwagę na przepis art. 7 ust. 6 ustawy o prokuraturze, który przewiduje, że w przypadku gdy w postępowaniu sądowym ujawnią się nowe okoliczności, prokurator samodzielnie podejmuje decyzje związane z dalszym tokiem tego postępowania ${ }^{35}$. Nowością jest, że jeżeli następstwem

${ }^{33}$ Odnosi się to jednak nie do każdego polecenia, ale tylko do tych, które dotyczą treści czynności procesowych, a więc do prowadzonego konkretnie postępowania przygotowawczego.

${ }^{34} \mathrm{O}$ tym, kto jest prokuratorem bezpośrednio przełożonym, stanowi art. $31 \S 1$ p.o.p. Jego analiza prowadzi do wniosku, że jeżeli polecenie wydał Prokurator Generalny, to dany podmiot nie może się w jakikolwiek sposób sprzeciwić jego wykonaniu, ponieważ nad Prokuratorem Generalnym nie ma prokuratora bezpośrednio przełożonego.

${ }^{35}$ Przepis ten został wprowadzony do ustawy o prokuraturze z dniem 8 sierpnia 1996 r. w wyniku nowelizacji ustawą z dnia 10 maja 1996 r. o zmianie ustaw o prokuraturze, o Sądzie Najwyższym, o Trybunale Konstytucyjnym oraz ustawy - Prawo o ustroju sądów powszechnych i ustawy - Prawo o adwokaturze (Dz.U., nr 77, poz. 367). Jak podaje M. Mistygacz (op. cit., s. 203), przepis ten wyraża francuską zasadę cechującą kontynentalne systemy prokuratury, 
decyzji może być konieczność dokonania wydatku przewyższającego kwotę ustaloną przez kierownika jednostki organizacyjnej, prokurator może podjąć decyzję po uzyskaniu zgody kierownika jednostki organizacyjnej.

Zasada podporządkowania jest więc w nowej ustawie o prokuraturze ukształtowana w sposób bardzo wyraźny. Dodatkowo analiza całej ustawy pozwala na wyróżnienie, oprócz prokuratora przełożonego, instytucji:

- prokuratora bezpośrednio przełożonego (art. 31 § 1, zob. art. $32 \S 1$, art. 64 $\S 2$, art. $173 \S 2$, art. $186 \S 1$ p.o.p.),

- przełożonego dyscyplinarnego (art. 144, zob. art. $150 \S 2$, art. $151 \S 1$ p.o.p.),

- zwierzchnika służbowego (art. $31 \S 2$, zob. art. $32 \S 1$, art. $37 \S 1$ i 2 , art. $39 \S 1$, art. $40 \S 2$ i 3 , art. $56 \S 2$ i art. $186 \S 2$ p.o.p.),

- prokuratora nadrzędnego (art. $33 \S 1$ p.o.p.) ${ }^{36}$,

- kierownika jednostki wyższego stopnia (art. 28, zob. art. 4 p.o.p.).

Powyższe historyczne przedstawienie niezależności prokuratury pokazuje, że nadal jest to bardzo kontrowersyjna instytucja. W literaturze dość powszechnie przyjmuje się niezależność jako zasadę ustrojową prokuratury ${ }^{37}$, jednak nie zawsze w sposób prawidłowy się ją definiuje, co jest związane z nierozróżnianiem jej aspektu zewnętrznego i wewnętrznego.

Nieraz błędnie art. $7 \S 1$ p.o.p. wiąże się tylko z elementem niepodporządkowania innym organom państwa ${ }^{38}$. Jest to nie do końca właściwe podejście, ponieważ przepis ten wyraźnie stanowi o niezależności prokuratora (jako osoby), a nie prokuratury (jako jednostki organizacyjnej). Jego sposób sformułowania i zastrzeżone wyjątki w in fine art. 7 § 1 p.o.p. prowadzą do wniosku, że odnosi się on tylko do niezależności wewnętrznej prokuratury (wobec przełożonych). $Z$ drugiej strony należy zauważyć, że niezależność zewnętrzna nie wynika z żadnego konkretnego przepisu ustawy, lecz jest związana ze sposobem ukształtowania prokuratury, a w szczególności chodzi tu o powiązanie Prokuratora Generalnego z innymi organami państwa.

zgodnie z którą „pióro ma być posłuszne, lecz słowo jest wolne” (la plum est serve, mais la parole est libre).

${ }^{36} \mathrm{~W}$ nowej ustawie - Prawo o prokuraturze definicja prokuratora nadrzędnego została przeniesiona z Kodeksu postępowania karnego (art. 45 § 1b k.p.k., art. 33 § 1 p.o.p.).

${ }^{37}$ Zob. J. Bodio, G. Borkowski, T. Demendecki, Ustrój organów ochrony prawnej. Część szczegółowa, Kraków 2005, s. 168; S. Włodyka, Ustrój organów ochrony prawnej, Warszawa 1975, s. 273; S. Waltoś, Proces karny. Zarys sytemu, Warszawa 2008, s. 171; K.T. Boratyńska, [w:] K.T. Boratyńska, Ł. Chojniak, W. Jasiński, Postępowanie karne, Warszawa 2015, s. 142; K. Marszał, Proces karny. Zagadnienia ogólne, Katowice 2008, s. 155; T. Grzegorczyk, [w:] T. Grzegorczyk, J. Tylman, Polskie postepowanie karne, Warszawa 2007, s. 258; K. Papke-Olszauskas, [w:] Prawo karne procesowe - część ogólna, red. J. Grajewski, Warszawa 2007, s. 187; C. Kulesza, [w:] Wykład prawa karnego procesowego, red. P. Kruszyński, Białystok 2004, s. 166-167; E. Samborski, Zarys metodyki pracy prokuratora, Warszawa 2008, s. 17-18.

${ }^{38}$ Zob. J. Bodio, G. Borkowski, T. Demendecki, op. cit., s. 168; S. Włodyka, op. cit., s. 273; K. Marszał, op. cit., s. 155; C. Kulesza, op. cit., s. 166-167. 
Poza tym T. Grzegorczyk zasadę niezależności rozumie jako wyraz tego, że prokurator nie musi uzyskiwać dla swych czynności uprzedniej aprobaty przełożonego ani też zatwierdzenia tych czynności ${ }^{39}$. Jednakże jest to bardziej zasada samodzielności, a nie niezależności. Ponadto w literaturze wyrażono pogląd, że:

[...] zasada niezależności stanowi cechę prokuratury, która logicznie wynika z funkcji przez nią pełnionych. Jako strażnik praworządności może efektywnie wypełniać zadania jedynie jako organ niezależny od innych organów władzy publicznej [...]. Niezależność nie może być oczywiście utożsamiana z niezawisłością. W odniesieniu do prokuratury niezależność ma charakter zewnętrzny, rozumiany jako niepodporządkowanie zewnętrznym organom. W stosunkach wewnętrznych w prokuraturze funkcjonuje zasada hierarchicznego podporządkowania, a więc przeciwieństwo zasady niezawisłości ${ }^{40}$.

Powyższe uwagi nie do końca są właściwe. Jeżeli porównujemy zależność Prokuratora Generalnego i innego organu państwa, to mówimy o niezależności zewnętrznej. Jeśli natomiast chodzi o stosunki wewnętrzne, to możemy mówić tylko o niezależności prokuratora i hierarchicznym podporządkowaniu. W sensie zewnętrznym nie możemy w związku z tym mówić o niezależności prokuratora, a jedynie o niezależności prokuratury w ujęciu ustrojowym. Zasadne byłoby więc mówienie o niezależności prokuratury i niezależności prokuratora jako odrębnych instytucjach prawnych, analogicznie jak o niezależności sądów i niezawisłości sędziego.

Od lat 90. ubiegłego wieku w literaturze można zaobserwować postulaty doktryny, aby stworzyć i ukształtować instytucję prokuratury jako organu jak najbardziej niezależnego ${ }^{41}$. Ponadto wysuwa się poglądy o konieczności wprowadzenia odpowiednich unormowań na temat prokuratury do Konstytucji ${ }^{42}$.

${ }^{39}$ T. Grzegorczyk, op. cit., s. 258.

${ }^{40}$ M. Mistygacz, op. cit., s. 201-202.

${ }^{41}$ Zob. Z. Brodzisz, Ustrój polskiej prokuratury a zasada niezależności prokuratorskiej, „Prokurator” 2011, nr 2, s. 24 i n.; J. Gurgul, Model prokuratury - ustrój i organizacja, „Prokuratura i Prawo" 1996, nr 9, s. 71 i n.; B. Mik, Nowe gwarancje niezależności prokuratury i prokuratorów - fakt czy iluzje, „Prokuratura i Prawo” 2010, nr 5, s. 102 i n.; H. Zięba-Załucka, Niezależność prokuratora w innych państwach na przykładzie Stanów Zjednoczonych Ameryki i Hiszpanii, [w:] Godność obywatela, urzędu i instytucji. Zmiany prawnoustrojowe prokuratury RP, red. H. Zięba-Załucka, M. Kijowski, Rzeszów 2005, s. 129-135; E. Zalewski, Prokuratura-zmiany, ale w którym kierunku, „Prokurator” 2007, nr 3-4, s. 81 i n.; B. Kurzępa, Prokuratura - organ do leczenia czy wymiany?, „Prokurator” 2003, nr 3-4, s. 7 i n.; E. Skrętowicz, Ewolucja przepisów o ustroju prokuratury i sądów powszechnych w latach 1984-1995, [w:] Kierunki i stan reformy prawa karnego, red. T. Bojarski, E. Skrętowicz, Lublin 1995, s. 59-65; E. Pływaczewski, Kilka uwag do projektu ustawy o Prokuraturze Rzeczypospolitej, [w:] Zasady procesu karnego wobec wyzwań wspótczesności. Księga ku czci Profesora Stanisława Waltosia, red. J. Czapska, A. Gaberle, S. Światłowski, A. Zoll, Warszawa 2000, s. 133-135, 139-141; A. Ważny, Konstytucja bez prokuratury, „Prokuratura i Prawo" 2009, nr 9, s. 114-117; F. Rymarz, Prokurator a sędzia. Pozycja ustrojowa i procesowa, „Prokuratura i Prawo” 1995, nr 7-8, s. 60-66; S. Waltoś, Prokuratura ..., s. 5-18.

${ }^{42}$ Zob. A. Ważny, op. cit., s. 114-117; A. Stankowski, Propozycja unormowań prokuratury w Konstytucji RP, „Prokuratura i Prawo” 2009, nr 10, s. 5-15; S. Iwanicki, Prokuratura w no- 
Co prawda, art. $7 \S 1$ p.o.p. nadal stanowi o niezależności (wewnętrznej) prokuratora. Połączenie funkcji Prokuratora Generalnego i Ministra Sprawiedliwości powoduje jednak, że prokuratura nie jest już niezależna zewnętrznie. Należy się jednocześnie zastanowić, czy jest jeszcze niezależna wewnętrznie. Każdy prokurator przełożony (a nie tylko bezpośrednio przełożony) oraz podmioty wymienione w art. $34 \S 1$ p.o.p. mają obecnie prawo wydawania wszelkiego rodzaju poleceń prokuratorowi niższego rzędu, także co do sposobu zakończenia postępowania. Nie ma więc już żadnych ograniczeń podmiotowych i przedmiotowych $\mathrm{w}$ prawie wydawania poleceń. Jest to zatem bardzo szerokie ingerowanie w samodzielność prokuratora podległego.

Jak trafnie zaznaczył S. Waltoś, „prawdą jest, że wyjątek potwierdza zasadę, nie zawsze jednak prawdą jest, że potwierdzają ją wyjątki. Jeśli obowiązujący system prawa przewiduje dużo wyjątków od zasady, to te wyjątki mogą już stanowić zasadę, choćby ustawa deklarowała zasadę przeciwną" ${ }^{\text {"33 }}$.

Jedyną gwarancją niezależności prokuratora jest art. $7 \S 4$ i 6 p.o.p. dotyczący prawa do żądania przez danego prokuratora zmiany polecenia, wyłączenia go od wykonania czynności lub od udziału w sprawie i uprawnienia go do samodzielnego podejmowania decyzji w toku postępowania sądowego, ale tylko wtedy, gdy ujawnią się nowe, nieprzewidziane wcześniej okoliczności. Te gwarancje są bardzo znikome w porównaniu z praktycznie nieograniczonym ingerowaniem przez prokuratorów przełożonych w czynności procesowe prokuratorów podległych. Prowadzi to do wniosku, że pomimo art. 7 § 1 p.o.p. nie można już mówić o zasadzie niezależności (wewnętrznej) prokuratora. Gwarancje niezależności są nieporównywalnie mniejsze niż wyjątki od niej. W konsekwencji, na gruncie obecnie obowiązującej ustawy - Prawo o prokuraturze, właściwie tylko zależność od przełożonych jest zasadą ustrojową.

Zupełnie w związku z tym niezrozumiałe jest powołanie Krajowej Rady Prokuratorów przy Prokuratorze Generalnym jako organu, który ma stać na straży niezależności prokuratorów (art. 43 § 1 p.o.p. $)^{44}$. Z drugiej strony można się zastanowić, czy prokuratura rzeczywiście powinna być zbudowana na zasadzie niezależności oraz czy nie logiczniej byłoby usunąć art. $7 \S 1$ p.o.p. Zależność prokuratorów od przełożonych również w literaturze nie zawsze powodowała negatywny oddźwięk.

R. Kmiecik zaznaczył, że:

[...] „niezależność” indywidualna poszczególnych funkcjonariuszy (prokuratorów) nie jest wcale rozwiązaniem gwarantującym sprawne realizowanie zadań tego urzędu, który pomimo ścisłego związku z sądownictwem opiera się przecież na zupełnie innych założeniach funkcjonalnych. Tylko niezależność prokuratury w wymiarze ustrojowym (w szczególności niezależność od

wej Konstytucji, „Prokuratura i Prawo” 1995, nr 2, s. 7-11; L. Mazowiecka, op. cit., s. 218-223; M. Mistygacz, op. cit., s. 293-307.

${ }^{43}$ Waltoś S., Proces karny..., s. 216.

${ }^{44}$ Ustawa nie precyzuje, jaką niezależność Krajowa Rada Prokuratorów ma chronić, ale należy się domyślać, że tylko wewnętrzną. 
władzy wykonawczej) jest postulatem, który powinien być traktowany jako zadanie legislacyjne pierwszorzędnej wagi. Autor nie popiera postulatu odstąpienia od zasady jednolitości i hierarchicznego podporządkowania na rzecz indywidualnej ,niezależności” poszczególnych prokuratorów $[\ldots]^{45}$.

Z tym poglądem nie zgodziła się H. Zięba-Załucka, która podkreśliła, że:

[...] nie tylko niezależność prokuratury w wymiarze ustrojowym (w szczególności niezależność od władzy wykonawczej) jest postulatem, który powinien być traktowany jako zadanie legislacyjne pierwszorzędnej wagi. Autorka poparła postulat odstąpienia od zasady jednolitości i hierarchicznego podporządkowania na rzecz indywidualnej „niezależności” poszczególnych prokuratorów $[\ldots]^{46}$.

Nie ulega wątpliwości, że następstwem zrealizowania postulatów H. Zięby-Załuckiej byłaby całkowita przebudowa struktury prokuratury. Zlikwidowaniu musiałaby ulec zasada podporządkowania, substytucji i dewolucji oraz prawo do wydawania wytycznych, zarządzeń i poleceń. W związku z tym może budzić wątpliwości racjonalność tak odmiennego ukształtowania systemu prokuratury.

Powyższe pokazuje, że zasada niezależności prokuratora jest istotną instytucją. Z jednej strony jest ukształtowanie prokuratury na zasadach hierarchicznego podporządkowania, a z drugiej - na zasadach niezależności, stojące do siebie w opozycji. Zasada hierarchicznego podporządkowania wymusza podział prokuratorów na przełożonych i podwładnych. Niezależność wewnętrzna nigdy nie będzie w pełni realizowana przy hierarchicznym podporządkowaniu prokuratorów.

Nie można jednak do tej kwestii podchodzić nazbyt krytycznie. Zależność prokuratora należy wiązać z funkcją, jaką on pełni. Chodzi tu w głównej mierze o prowadzenie postępowania przygotowawczego. Trzeba bowiem zauważyć, że ten etap procesu karnego jest oparty na zasadach inkwizycyjności, tajności, bardzo ograniczonej kontradyktoryjności i działania organu z urzędu. Postępowanie sądowe ma natomiast zupełnie inny charakter, ponieważ dominuje w nim jawność, kontradyktoryjność i skargowość. Dlatego organy sądowe są zbudowane na zasadach niezawisłości i niezależności. Przed błędami orzeczniczymi w sądach chroni zasada kontroli odwoławczej i w pewnych warunkach kolegialność składu orzekającego, zaś w prokuratorze jest to prawo zmiany decyzji przez prokuratora przełożonego. Charakter postępowania przygotowawczego nie wymusza co do zasady, aby organy ścigania legitymowały się analogicznymi gwarancjami, jak sądy. Jedynie co do pewnych instytucji w postępowaniu przygotowawczym, aby zagwarantować ich rzetelność, zastrzeżono kompetencję sądu (np. co do tymczasowego aresztowania). Prawo sądu do przeprowadzania wybranych czynności w postępowaniu przygotowawczym jest swego rodzaju wyrazem braku zaufania ustawodawcy do niezależności i bezstronności prokuratora.

${ }^{45}$ R. Kmiecik, Prokuratura w „,demokratycznym państwie prawnym” (refleksje sceptyczne), „Prokurator” 2000, nr 1, s. 16.

${ }^{46}$ H. Zięba-Załucka, Instytucja prokuratury..., s. 146-147. 
Reasumując, ograniczona niezależność wewnętrzna w prokuraturze nie rodzi zbytniego niebezpieczeństwa nieprawidłowego funkcjonowania prokuratury, chociaż najbardziej optymalnym rozwiązaniem jest przyznanie tylko prokuratorowi bezpośrednio przełożonemu prawa wydawania poleceń dotyczących treści czynności procesowych. Poza tym polecenia przełożonych nigdy nie powinny odnosić się do sposobu zakończenia postępowania przygotowawczego. Brak niezależności zewnętrznej jest natomiast największą wadą w sposobie funkcjonowania prokuratury, ponieważ często może to prowadzić do sytuacji, że prokuratura będzie wykorzystywana do doraźnych celów politycznych, a nie do stania na straży praworządności i ścigania przestępstw.

\section{BIBLIOGRAFIA}

Auscaler G., O Prokuraturze Rzeczypospolitej Polskiej, „Wojskowy Przegląd Prawniczy” 1950, nr 2.

Bednarzak J., Prokuratura w 35-leciu PRL, „Nowe Prawo” 1979, nr 9.

Bodio J., Borkowski G., Demendecki T., Ustrój organów ochrony prawnej. Część szczegółowa, Kraków 2005.

Boratyńska K.T., [w:] K.T. Boratyńska, Ł. Chojniak, W. Jasiński, Postępowanie karne, Warszawa 2015.

Brodzisz Z., Ustrój polskiej prokuratury a zasada niezależności prokuratorskiej, „Prokurator” 2011, nr 2.

Grzegorczyk T., [w:] T. Grzegorczyk, J. Tylman, Polskie postępowanie karne, Warszawa 2007.

Grzeszczyk W., Nowy ksztalt ustawy o prokuraturze, [w:] Prokuratura, ustawa, regulamin, inne przepisy, red. W. Czerwiński, Toruń 1997.

Gurgul J., Model prokuratury - ustrój i organizacja, „Prokuratura i Prawo” 1996, nr 9.

Gurgul J., Prokurator w II Rzeczypospolitej-zagadnienia wybrane, „Prokuratura i Prawo” 1999, nr 11-12.

Herzog A., Niezależność prokuratury - mit czy nadzieja?, „Prokuratura i Prawo” 2009, nr 1.

Iwanicki S., Prokuratura w nowej Konstytucji, „Prokuratura i Prawo” 1995, nr 2.

Kalinowski S., Polski proces karny, Warszawa 1971.

Kiełtyka A., Skrzypek R., Gadzała A., Ochrona konstytucyjnych praw i wolności człowieka i obywatela w działalności prokuratury Rzeczypospolitej Polskiej, [w:] Godność obywatela, urzędu i instytucji. Zmiany prawnoustrojowe prokuratury RP, red. H. Zięba-Załucka, M. Kijowski, Rzeszów 2005.

Kmiecik R. Prokuratura w „,demokratycznym państwie prawnym” (refleksje sceptyczne), „Prokurator" 2000, nr 1.

Konic J.S., Uwagi ogólne o umiejscowieniu prokuratury $w$ systemie organów państwowych, „Nowe Prawo" 1957, nr 11.

Konstytucja PRL z dnia 22 lipca 1952 r. (Dz.U. z 1952 r., nr 33, poz. 232).

Kulesza C., [w:] Wyktad prawa karnego procesowego, red. P. Kruszyński, Białystok 2004.

Kurzępa B., Prokuratura - organ do leczenia czy wymiany?, „Prokurator” 2003, nr 3-4.

Lityński A., O prokuraturze, prokuratorze i procedurze (1944-1950). Uwag kilka, [w:] Zasady procesu karnego wobec wyzwań współczesności. Księga ku czci Profesora Stanisława Waltosia, red. J. Czapska, A. Gaberle, A. Światłowski, A. Zoll, Warszawa 2000.

Łysko M., Prokuratorski nadzór ogólny w Polsce w latach 1950-1967, Białystok 2006. 
Marszał K., Proces karny. Zagadnienia ogólne, Katowice 2008.

Mazowiecka L., Prokuratura w Polsce (1918-2014), Warszawa 2015.

Mik B., Nowe gwarancje niezależności prokuratury i prokuratorów - fakt czy iluzje, „Prokuratura i Prawo" 2010, nr 5.

Mistygacz M., Ustrój prokuratury w Polsce. Tradycja i współczesność, Warszawa 2013.

Papke-Olszauskas K., [w:] Prawo karne procesowe - część ogólna, red. J. Grajewski, Warszawa 2007.

Pływaczewski E., Kilka uwag do projektu ustawy o Prokuraturze Rzeczypospolitej, [w:] Zasady procesu karnego wobec wyzwań współczesności. Księga ku czci Profesora Stanistawa Waltosia, red. J. Czapska, A. Gaberle, S. Światłowski, A. Zoll, Warszawa 2000.

Rozporządzenie Prezydenta RP z dnia 6 lutego 1928 r. - Prawo o ustroju sądów powszechnych (Dz.U., nr 12, poz. 93).

Rymarz F., Prokurator a sędzia. Pozycja ustrojowa i procesowa, „Prokuratura i Prawo” 1995, $\mathrm{nr} 7-8$.

Samborski E., Zarys metodyki pracy prokuratora, Warszawa 2008.

Schaff L., Proces karny Polski Ludowej. Wykład zasad ogólnych, Warszawa 1953.

Skrętowicz E., Ewolucja przepisów o ustroju prokuratury i sądów powszechnych w latach 19841995, [w:] Kierunki i stan reformy prawa karnego, red. T. Bojarski, E. Skrętowicz, Lublin 1995.

Słownik języka polskiego, red. M. Szymczak, t. 2, Warszawa 1984.

Smoleński J., Nowa ustawa o Prokuraturze PRL, „Państwo i Prawo” 1967, z. 8-9.

Smoleński J., Prawno-ustrojowe problemy prokuratury, „Państwo i Prawo” 1963, z. 1.

Smoleński J., Prokuratura Polskiej Rzeczypospolitej Ludowej. Komentarz do ustawy o prokuraturze PRL i innych przepisów dotyczacych prokuratury, Warszawa 1981.

Stankowski A., Propozycja unormowań prokuratury w Konstytucji RP, „Prokuratura i Prawo” 2009, nr 10.

Stembrowicz J., Prokuratura wedtug nowej ustawy. Zagadnienia wybrane, „Państwo i Prawo” 1968, z. 6.

Śliwiński S., Polski proces karny przed sądem powszechnym. Zasady ogólne, Warszawa 1961.

Ustawa z dnia 20 lipca 1950 r. o prokuraturze (Dz.U., nr 38, poz. 346).

Ustawa z dnia 14 kwietnia 1967 r. o Prokuraturze PRL (Dz.U., nr 13, poz. 55).

Ustawa z dnia 20 czerwca 1985 r. o prokuraturze (Dz.U. z 1985 r., nr 31, poz. 138).

Ustawa z dnia 29 grudnia 1989 r. o zmianie Konstytucji PRL (Dz.U., nr 75, poz. 444).

Ustawa z dnia 22 marca 1990 r. o zmianie ustawy o Prokuraturze PRL, Kodeksu postępowania w sprawach o wykroczenia oraz ustawy o Sądzie Najwyższym (Dz.U., nr 20, poz. 121).

Ustawa z dnia 6 kwietnia 1990 r. o Policji (Dz.U. z 2015 r., poz. 359 z późn. zm.).

Ustawa z dnia 10 maja 1996 r. o zmianie ustaw o prokuraturze, o Sądzie Najwyższym, o Trybunale Konstytucyjnym oraz ustawy - Prawo o ustroju sądów powszechnych i ustawy - Prawo o adwokaturze (Dz.U., nr 77, poz. 367).

Ustawa z dnia 24 maja 2002 r. o Agencji Bezpieczeństwa Wewnętrznego i Agencji Wywiadu (Dz.U. z 2010 r., nr 29, poz. 154 z późn. zm.).

Ustawa z dnia 9 października 2009 r. o zmianie ustawy o prokuraturze oraz niektórych innych ustaw (Dz.U., nr 178, poz. 1375).

Ustawa z dnia 28 stycznia 2016 r. - Prawo o prokuraturze (Dz.U., poz. 177).

Waltoś S., Karnoprocesowe konsekwencje nowej ustawy o prokuraturze, „Nowe Prawo” 1967, nr 9.

Waltoś S., Proces karny. Zarys sytemu, Warszawa 2008.

Waltoś S., Prokuratura - jej miejsce wśród organów władzy, struktura i funkcje, „Państwo i Prawo" 2002, z. 4.

Ważny A., Konstytucja bez prokuratury, „Prokuratura i Prawo” 2009, nr 9. 
Winawer W., O miejsce prokuratury w systemie organów państwowych, „Nowe Prawo” 1957, nr 6. Włodyka S., Ustrój organów ochrony prawnej, Warszawa 1968. Włodyka S., Ustrój organów ochrony prawnej, Warszawa 1975. Zalewski E., Prokuratura-zmiany, ale w którym kierunku, „Prokurator” 2007, nr 3-4. Zięba H., Organizacja i funkcje prokuratury PRL, Rzeszów 1984.

Zięba-Załucka H., Instytucja prokuratury w Polsce, Warszawa 2003.

Zięba-Załucka H., Niezależność prokuratora w innych państwach na przykładzie Stanów Zjednoczonych Ameryki i Hiszpanii, [w:] Godność obywatela, urzędu i instytucji. Zmiany prawnoustrojowe prokuratury RP, red. H. Zięba-Załucka, M. Kijowski, Rzeszów 2005.

\section{SUMMARY}

The article concerned raises the problem of the prosecutor's autonomy. In the article the evolution and a way of shaping of the prosecutor's autonomy in the historical aspect are presented and then the analysis of the autonomy is made in the Act - Law on the Prosecutor's Office. The main point of the article is the emphasising the need of distinguishing the issue of the external autonomy of the Prosecutor's Office (as the organizational unit) and the internal prosecutor's autonomy (as the relation between the supervisor and the subordinate). As far as the external autonomy is concerned the particular attention is dedicated to the issue of joining the function of the Minister of Justice and the Prosecutor General. The author has also put forward the proposal that in the new Act - Law on the Prosecutor's Office we can not say any more about the prosecutor's autonomy as the systemic rule. At the end the views are analysed concerning the need and the usefulness of forming the Prosecutor's Office on the rule of the autonomy. The author described also his/her own view on the most optimal way of creation of the prosecutor's autonomy.

Keywords: rule of the prosecutor's autonomy in the internal and external aspect; prosecutor's autonomy in the historical aspect; issue of joining the position of the Ministry of Justice and the Prosecutor General 